\title{
PRINSIP DAN KONSEP TEORI MORAL ALAMIAH DALAM NOVEL SA.B.A!
}

\section{(The Principles and Concepts of Natural Moral Theory in the Novel Sa.b.a! )}

\author{
Chong Ah Fok \\ Brunei Darussalam
}

Published online: 3 December 2018

To cite: Chong Ah Fok. (2018). Prinsip dan konsep teori moral alamiah dalam novel Sa.b.a!. Malay Literature 31(2), 311 - 331.

\begin{abstract}
Abstrak
Kajian dalam makalah ini menerapkan prinsip dan konsep teori moral alamiah pada struktur permukaan terhadap novel Sa.b.a!. Novel ini karya Haji Abdul Aziz Tuah, penerima SEA Write Award 2015 untuk negara Brunei Darussalam. Perbincangan dalam makalah ini mengungkapkan novel berdasarkan konsep dan prinsip teori moral alamiah. Novel ini didapati menepati keadaan, kejadian dan proses pembentukan alam ciptaan Tuhan. Kajian ini memperlihatkan bahawa novel hasil ciptaan pengarang itu berlaku dengan adanya restu Tuhan. Pengarang sama seperti unsur alam yang lain mampu membentuk sesuatu yang akhirnya menjadi sumber alam juga. Dalam hal ini karya sastera (novel) yang menggabungkan pengalaman dan ilmu pengetahuan menjadikan teks sebagai sumber alam ciptaan pengarang. Sementara itu naratif di dalamnya dapat disamakan dengan mimpi yang mengandungi peristiwa yang misteri bentuknya, namun ada pengalaman dan ilmu di dalamnya. Pembentukan teks novel ini seperti kejadian alam yang mempunyai kepelbagaian, keseimbangan dan keharmonian. Kewujudan atau penciptaannya tidak sia-sia tetapi mengandungi manfaat, sesuai dengan kejadiannya yang berfaedah dan indah sebagai iktibar kepada manusia.
\end{abstract}

Kata kunci: alamiah, pencipta, mimpi, objek, naratif, permukaan 


\begin{abstract}
This paper examines the principles and concepts of natural moral theory in the novel "Sa.b.a!", the works of Haji Abdul Aziz Tuah who is the recipient of the 2015 SEA Write Award for Brunei Darussalam, on its surface structure. The discussion in this paper is to express this novel in conformity with the principles and concepts of nature moral theory, which is meet the situation, events and processes of nature the creation of God. This study shows that the novel of the author's creation has occurred with God's blessing. Author, like other nature elements are capable of forming something that eventually becomes a source of nature as well. In this case the literary work (novel) that combines experience and knowledge into text becomes the source of nature the author's creation. Meanwhile narratives in novel can be likened as a dream that contains a mysterious event but there is experience and knowledge in it. The formation of this novel's text is like natural occurrence of nature that has diversity, balance and harmony. Its existence or creation is not futile but it contains usefulness in accordance with nature occurrence, beneficial and beautiful, as a lesson to human beings.
\end{abstract}

Keywords: nature, creator, dream, object, narrative, surface

\title{
PENGENALAN
}

Karya sastera ialah produk manusia kreatif yang menggunakan bahasa konotatif. Biasanya manusia kreatif bernama pengarang menghasilkan karya bertulis. Sebahagiannya dikenali sebagai dalang, pawang, batil, penglipur lara, pendiang dangan dan lain-lain. Kewujudan karya sastera memperkaya kebudayaan sesuatu bangsa yang juga melambangkan ketamadunannya. Bangsa yang bertamadun tinggi ialah bangsa yang berjaya melahirkan pengarang yang menghasilkan karya magnum opus. Karya yang demikian sangat bermanfaat sama seperti alam yang dijadikan Tuhan. Manfaatnya bukan terletak pada keindahan dari segi bentuk sahaja namun yang lebih penting ialah keindahan isi atau makna yang terkandung di dalamnya. Oleh itu, para sarjana perlu mengkaji karya sastera untuk mendedahkan manfaatnya kepada masyarakat. Di samping itu, kajian ini juga bertujuan untuk menempatkan sesuatu hasil karya kreatif-sastera itu pada suatu kedudukan yang sesuai. Penilaian demikian tidak semestinya ditekankan dalam kajian. Melalui pendedahan yang objektif, sudah tentu masyarakat mendapat gambaran mengenai sesebuah karya yang didedahkan itu. 
Dalam kesempatan ini novel "Sa.b.a!" (S) sebagai objek kajian yang hendak dianalisis. Novel ini telah mengangkat penulisnya, Haji Abdul Aziz Tuah atau nama pena JaBiT Abdul Aziz, yang berjaya menerima SEA Write Award yang berprestij di rantau Nusantara ini, khususnya bagi negara Brunei Darussalam, pada 2015 di Bangkok, Thailand. Berdasarkan prakata pengarah DBP yang tercatat dalam novel tersebut, novel $S$ berjaya dilahirkan hasil daripada bengkel yang diikuti oleh pengarangnya di Bogor, Jakarta pada tahun 2001. Oleh sebab itu, pada kulit novel ini ada dicatatkan khusus "karyawan Bengkel MASTERA" dengan logo MASTERA, sebagai penanda bahawa bengkel yang dikendalikan oleh Indonesia itu berjaya melahirkan penulis novel. Sejauh ini rasanya belum ada pengkaji yang mengetengahkan novel ini kepada khalayak untuk dinikmati, dicerna dan dihayati. Sebagai sebuah karya yang diangkat sedemikian tinggi, tentu ada keistimewaannya. Kajian ini akan menerapkan teori moral alamiah (Chong, 2016) untuk mendedahkan keistimewaan novel tersebut.

\section{PRINSIP DAN KONSEP TEORI MORAL ALAMIAH}

Teori moral alamiah ini wujud berdasarkan prinsip dan konsep utama Pengkaedahan Melayu janaan Hashim Awang (1989), hasil usaha beliau untuk menghindarkan sarjana tempatan daripada terus terjerumus ke dalam pemikiran "Lubang Biawak". "Lubang Biawak" ialah jargon ahli jiwa Islam dari Sudan yang bernama Malek B. Badri yang bermaksud golongan intelektual di dunia Islam yang sering mengikut apa-apa sahaja tindakan atau pendapat golongan intelektual dari Barat secara membuta tuli (1989, pp. 1 -2). Teori Hashim Awang ialah teori mandiri yang berjaya menarik minat beberapa orang sarjana di Malaysia dan juga Brunei yang tidak mahu masuk ke "Lubang Biawak" yang dikatakan oleh Malek B. Badri. Hasil daripada penelitian penulis terhadap pengkaedahan Melayu itu timbul satu pemikiran baharu untuk membuat sedikit perubahan terhadap teori tersebut dan menjenamakannya sebagai teori moral alamiah.

Prinsip utama teori ini ialah karya sastera sebagai kejadian alam yang bermanfaat, mengandungi bentuk, proses, sistem, estetik sama ada dalam bentuk lisan ataupun tulisan. Naratifnya mengandungi cerita, pengalaman dan ilmu. Struktur komponen tersebut terdapat dalam dua lapisan; lapisan permukaan dan lapisan dasar. Kedua-dua lapisan itu saling memperkasa untuk membentuk makna bagi kepentingan manusia kerana kewujudan karya sastera itu seperti juga kewujudan alam natural (semula jadi); bersebab, bermatlamat serta bermanfaat kepada manusia. Alam semula jadi yang 
dimaksudkan itu mencakupi bumi dan langit serta sistem planetnya meliputi kosmogoni dan kosmografinya, yang dilihat dari perspektif masyarakat Melayu-Islam, dijadikan oleh Tuhan (Chong, 2016). Antara contohnya termasuklah keberadaan atau kewujudan tasik disebabkan gempa atau letusan gunung berapi, ataupun sarang yang dijalin atau dibuat oleh burung. Demikian juga dengan karya sastera yang dapat dianggap sebagai sebahagian daripada objek alam seperti tasik dan sarang burung yang kewujudannya hasil proses oleh objek ciptaan Tuhan. Objek tersebut (termasuk pengarang) mampu mencipta atau membuat sesuatu dengan adanya izin Tuhan kepada mereka. Pendapat ini sesuai dengan tulisan Wellek dan Warren (1988, p.12) mengatakan bahawa sajak itu ialah objek. Oleh itu, karya sastera itu juga objek dan naratifnya sebagai subjek. Kedua-duanya telah dicipta oleh pencipta (pengarang) yang disimpulkan sebagai "karya sastera" itu mengandungi manfaat yang berbeza-beza namun sentiasa saling mendukung. Secara umumnya karya sastera itu dapat digambarkan seperti Rajah 1.

Sebagai objek, ciri-ciri karya sastera yang mengandungi komponen seperti dalam Rajah 1 yang ada persamaan dengan ciri-ciri alam, iaitu:

(a) Kesatuan/kebulatan yang menyeluruh - alam terbina daripada unsur bumi (tanah), langit, laut (air), tumbuh-tumbuhan, haiwan, dan manusia. Setiap satu unsur itu saling berhubungan dan saling memperkuat, serta mempunyai fungsi khusus masing-masing.

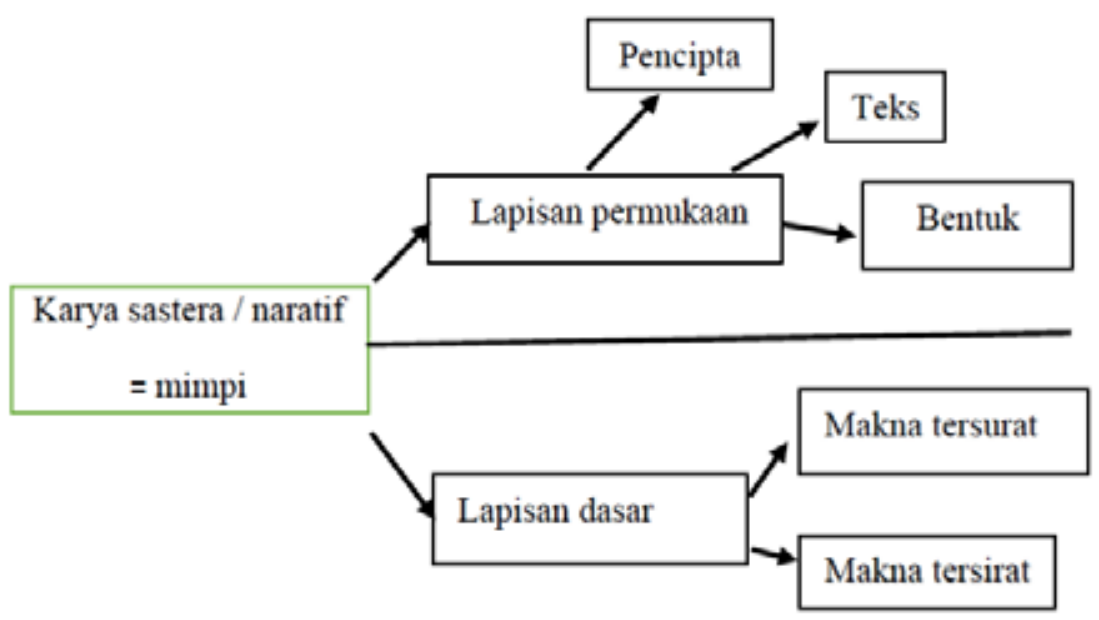

Rajah 1 Gambaran karya sastera. 
(b) Kedinamikan - unsur-unsur yang membina alam itu sentiasa berada dalam keadaan bergerak dan berubah-ubah tidak statik untuk kesempurnaan dan kepentingan makhluk.

(c) Keselarasan dan keharmonian - setiap unsur pembinaan alam ada ukuran dan ketepatan melahirkan keselarasan dan keindahan.

(d) Kepelbagaian - terdapat kepelbagaian dari segi bentuk serta unsur-unsur di dalam alam, umpamanya fauna dan flora dan jenis-jenis masingmasing.

(e) Keteraturan/ketertiban - kejadian alam begitu sempurna yang mempunyai keteraturannya masing-masing dengan kehendak Tuhan.

(f) Keindahan - alam amat tinggi nilai keindahannya, ciptaan Tuhan.

Karya sastera merupakan teks yang berjaya dicipta oleh manusia melalui proses interaksi, interpretasi, dan integrasi secara horizontal dan vertikal dengan alam (fauna, flora serta sistem planet termasuk manusia dan segala interaksi atau disebut kehidupan). Pembentukan karya sastera melalui satu proses yang melibatkan pengalaman dan ilmu atau pengetahuan yang diadun dalam naratif dan cerita. Naratif dalam karya sastera itu, berdasarkan teori moral alamiah, disamakan dengan mimpi (subjek alam) kerana sesebuah cereka itu merupakan buah fikiran penulisnya yang ditulis berdasarkan daya imaginasi serta pengalamannya. Naratif dilahirkan secara sedar ataupun tidak sedar (Chong, 2008, p.156). Hal tersebut hampir sama dengan kejadian mimpi. Mimpi merupakan pengalaman bawah sedar yang melibatkan emosi, perasaan, fikiran, penglihatan, pendengaran, dan indera lainnya yang terjadi pada saat kita sedang tidur (http://www.primbon.com/tafsir_mimpi.htm). Daripada bahan internet yang dikutip ini juga menjelaskan bahawa Aristotle (384 - 322 SM) mengemukakan pandangannya tentang mimpi. Menurut Aristotle, mimpi merupakan aktiviti mental ketika seseorang tidur. Saat tidur, indera tetap dapat menangkap rangsangan daripada luar. Rangsangan itu kemudian diperbesar melalui mimpi. Kewujudan karya sastera itu pun demikian juga. Walaupun karya sastera digarap ketika penciptanya dalam keadaan sedar tetapi bahan-bahan yang dikembangkan dalam naratifnya juga merupakan pengalaman yang diperbesar.

Macrobius dan Artemidorus (http://www.primbon.com/tafsir_mimpi. htm) membahagikan mimpi itu kepada dua kategori, iaitu: 
(a) Mimpi yang berkaitan dengan masa lalu dan masa sekarang, iaitu peristiwa yang telah berlaku dan sedang berlaku.

(b) Mimpi yang berkaitan dengan masa depan. Dalam hal ini, mimpi yang bermakna membawa pesan tentang peristiwa yang akan terjadi. Dalam kategori ini, peristiwa yang tergambar itu boleh juga dalam bentuk yang tidak masuk akal (sekurang-kurangnya pada masa sekarang). Mimpi ini dibahagikannya kepada tiga, iaitu: Oraculum (mimpi kenabian atau mimpi yang membawa pesan daripada Tuhan), Visio (mimpi yang meramalkan peristiwa yang akan terjadi pada masa depan, dan Somnium (mimpi simbolis yang ditafsirkan atau diertikan maknanya secara hati-hati).

Seterusnya teori moral alamiah ini menekankan kegunaan atau manfaat karya sastera. Setiap objek alam dan subjek alam yang wujud di dunia ini ada kegunaannya. Demikian juga dengan karya sastera itu. Dalam hubungan ini karya sastera itu sama seperti alam yang dapat melahirkan dua fungsi;

(a) Membekalkan pengalaman dan pengetahuan yang tidak akan habishabis diteroka (semakin banyak pengalaman dan pengetahuan diperoleh, semakin banyak lagi yang perlu diketahui).

(b) Memberikan perbandingan asli dan segar dalam hubungan manusia dan kehidupannya.

Prinsip ini memandang karya sastera itu mengandungi nilai sosial, ekonomi malah politik yang boleh dijadikan pengetahuan dan pengalaman (ilmu) kepada pembaca. Oleh sebab karya sastera mengandungi cerita dan juga ilmu di dalamnya maka dikatakan mencontohi al-Quran seperti yang disebut Hashim (2002, p. 18), iaitu:

Karya sastera dalam pendekatan ini (pendekatan alamiah) harus mampu mencontohi kitab suci al-Quran yang memiliki nilai ketinggian: dalamnya terkandung pelbagai ilmu pengetahuan, pengisahan berbagai-bagai jenis dan perlakuan manusia untuk dipelajari dan dicontohi, penyampaian nasihat dan ajaran, dan kepentingan kepada bentuk serta keindahan". 
Karya sastera ialah cerita yang bermanfaat. Pandangan Hashim di atas, menegaskan bahawa cerita dalam karya sastera bukan sekadar cerita kosong. Karya sastera sesuai dengan objek kejadian alam yang kejadiannya bukanlah sia-sia. Cerita dalam karya sastera menawarkan pengetahuan dan pengalaman. Kedua-dua perkara itu disampaikan melalui cerita. Ciri ini mencontohi al-Quran, dan pandangan ini dipersetujui oleh Ainon (2011, p. 25), iaitu:

Menulis cerita panjang, istilah sekarang "novel", ada sunahnya, baik di dalam al-Quran mahupun rekod-rekod hadis. Jadi menulis cerita adalah suatu aktiviti yang bernilai ibadah. Kitab al-Quran itu penuh dengan pelbagai cerita, daripada cerita yang ringkas-ringkas kepada cerita-cerita yang panjang. Dua cerita yang panjang dalam alQuran ialah kisah hidup Nabi Yusuf dan Nabi Musa. Ini bermakna, cerita panjang menjadi alat penting bagi menyampaikan mesej. Nabi Muhammad, walaupun beliau tidak menulis cerita, tetapi beliau banyak menggunakan cerita bagi menyampaikan mesej sebagaimana yang terdapat dalam rekod hadis-hadis beliau."

Dengan hal yang demikian, teori moral alamiah melihat sesuatu karya sastera itu bukan hanya sekadar naratif yang mengandungi cerita tetapi juga ilmu dan pengetahuan serta pengalaman di dalamnya. Kedua-dua perkara ini sangat berguna kepada manusia untuk membangunkan diri, masyarakat, negara malah dunia dari segi sosioekonomi, sosiobudaya dan sosiopolitik. Perkara inilah yang dimaksudkan "moral" dalam teori ini, iaitu sesuatu yang boleh dijadikan iktibar serta memperkaya ilmu pengetahuan pembaca dan seterusnya dapat dimanfaatkan dalam kehidupan. Malah mengikut Seyyed Hossein (1993, p. 103) karya sastera dapat dimanfaatkan oleh para ahli kerohanian untuk mencapai tahap yang lebih tinggi dalam perjalanan spiritual mereka. Perkara ini diperoleh daripada bentuk dan isi (makna) teks. Namun begitu, perlu diingat bahawa kecacatan bentuk tidak mencacatkan isinya dan masih dapat dimanfaatkan. Sebaliknya, kecacatan isi menyebabkan sesuatu karya itu hilang fungsinya dan tidak dapat dimanfaatkan lagi secara maksimum (Muhammad Lutfi, 2016, p. 5). Berdasarkan pendapat beliau itu, karya sastera bermanfaat untuk meningkatkan lagi mutu kehidupan manusia jika isinya bermutu (mengandungi ilmu pengetahuan dan nilai estetika yang tinggi). Wellek dan Warren (1988, p. 12) menyatakan bahawa "setiap objek itu atau jenis objek digunakan dalam cara yang paling berkesan dan rasional berdasarkan apakah objek itu sebenarnya, ataupun apakah objek 
itu pada dasarnya”. Walau bagaimanapun, kegunaan atau manfaat karya sastera itu bergantung pada kita yang menilai atau menggunakannya. Secara alamiah, objek (teks) dan subjek (peristiwa dalam naratif/cerita teks) itu ada kegunaannya mengikut keperluan pembaca. Ilmu dalam karya sastera itu mengandungi makna tersurat dan juga makna secara tersirat. Makna yang kedua ini hanya diperoleh setelah memahami cerita atau dengan mentakwilkan cerita itu. Kesimpulannya, teori moral alamiah ini melihat karya sastera itu sebagai objek dan juga sebagai subjek secara permukaan dan dasar yang boleh dijadikan iktibar.

\section{ANALISIS NOVEL SA.B.A!}

Kewujudan karya sastera sama seperti alam yang lain mengandungi dua fungsi; fungsi sebagai objek dan fungsi sebagai subjek. Kedua-duanya, sama ada sebagai objek mahupun subjek mengandungi manfaatnya yang tersendiri mengikut lumrahnya alamiah. Kemanfaatan sesuatu karya sastera itu boleh dilakukan secara permukaannya dan juga dalamannya. Dalam kajian ini, analisis hanya ditumpukan pada lapisan permukaannya sahaja, iaitu tidak membicarakan lapisan dasar mengenai isi dalam novel Sa.b.a.! (S).

\section{Karya Sastera sebagai Objek Alam}

Berdasarkan teori moral alamiah, yang dianggap sebagai objek alam itu bukan hanya karya sastera tetapi juga pencipta-pengarangnya. Penciptanya ialah sebahagian daripada unsur alam yang dengan izin Tuhan berkemampuan untuk mencipta karya sastera. Dalam urutannya, karya sastera itu ialah ciptaan kedua selepas pengarang diciptakan. Pengarang ialah ciptaan Tuhan. Pengarang sama seperti binatang, sungai dan cakerawala mampu mewujudkan sesuatu yang belum wujud sebelumnya. Peranannya sama juga dengan pencipta yang lain seperti jurutera, arkitek, ahli sains, pelukis dan seumpamanya yang menghasilkan sesuatu objek alam untuk kegunaan manusia. Sebagai contoh, arkitek menghasilkan pelan yang akhirnya direalisasikan menjadi bangunan, pelukis melukis dan menghasilkan lukisan. Jadi, pelan rumah, bangunan dan lukisan itu juga objek alam. Sementara itu, pengarang pula menghasilkan karya sastera yang akhirnya juga menjadi objek alam. Pendeknya, karya sastera itu sebagai objek alam kerana pembentukannya sama dengan unsur alam yang lain, iaitu ada pencipta dan ada bentuk objek yang diwujudkannya. 


\section{Pencipta atau Pengarang Novel $S$}

Seperti yang dinyatakan di atas, pengarang merupakan sebahagian daripada objek alam ciptaan Tuhan yang diizinkan oleh Tuhan untuk melahirkan karya kreatif (objek alam ciptaan manusia) yang menepati piawaian tertentu. Novel $S$ ialah objek alam yang dihasilkan oleh JaBiT Abdul Aziz (objek alam). Daripada ratusan ribu penduduk di negara Brunei Darussalam ini, hanya pengarang ini yang berjaya melahirkan novel ini dengan tujuan tertentu. Salah satu daripadanya dan yang pasti pengarangnya ingin berkongsi pengalaman dan ilmunya kepada pembaca. Pengarang ini berharap karyanya akan menjadi bahan pemikiran pembaca dan seterusnya merobah persepsi atau mengubah sesuatu pandangan pembaca mengenai kampung air. Selama ini, kebanyakan orang melihat kampung air kerana keunikannya dan mungkin tidak terfikir bahawa di kampung air itu perlu ada pembaharuan seperti yang dilakukan oleh watak Daniel bin Sahak dalam novel $S$.

Novel ini tidak lahir begitu sahaja, tetapi melalui proses, iaitu sama seperti kejadian unsur alam yang lain. Setelah membaca novel $S$, didapati bahawa kelahiran melalui proses yang diusahakan oleh pengarangnya, JaBiT Abdul Aziz. Selain mengumpulkan pengalaman berdasarkan latar belakang hidupnya dan ilmu pengetahuan dalam sesuatu bidang tertentu (sejarah, kewartawanan, dan peguam) yang diperolehnya selama ini, dia juga menimba ilmu kepengarangan daripada bengkel penulisan novel MASTERA, di Bandung Indonesia. Untuk memperdalam ilmu yang diterapkan dalam novel itu pengarangnya telah melakukan penyelidikan melalui internet. Semua ilmu yang diperoleh diadun dan disisipkannya dalam naratif novel yang dinamakannya Sa.b.a! ini.

Selain itu, pengalaman pengarang (hasil pembacaannya - antara pengalamannya) bukan sahaja tergambar dalam naratif teksnya tetapi juga dari segi bentuk novel, iaitu termasuklah tulisan, saiz fon, penyusunan bab dan sebagainya kerana novel yang demikian itu telah pernah ditulis oleh penulis tempatan sebelumnya seperti Mussidi dan Rahimi AB. Jadi, novel ini bukan terjadi atau terbentuk sebagai objek alam dengan sekelip mata. Walaupun berkemungkinan novel ini berjaya disiapkan dalam masa beberapa bulan, namun pengalaman dan ilmu yang dijadikan asas penulisannya jauh lebih lama pengumpulannya sebelum berjaya diterapkan oleh pengarang dalam novel ini. Dengan demikian, pengarang novel $S$ ini menunjukkan keseriusannya dalam penghasilan novel ini. 


\section{Teks Novel $S$}

Objek alam hasil ciptaan JaBiT Abdul Aziz ialah teks novel $S$. Teks ini dikatakan sebagai objek kerana kejadiannya sama seperti unsur alam yang lain; mempunyai bentuk, dapat dipegang, dan dapat dilihat. Bentuk novel $S$ sebagai teks mempunyai ciri-ciri khas, iaitu selain sebagai hasil ciptaan JaBiT Abdul Aziz, novel ini diterbitkan oleh Dewan Bahasa dan Pustaka Brunei tahun 2010 (cetakan pertama) dengan ISBN 99917-0-698-4. Novel ini mengandungi 239 muka surat yang boleh dibahagikan kepada prakata daripada Hajah Aminah binti Haji Momin selaku Pemangku Pengarah (2 muka surat), isi teks/naratif (203 halaman), lampiran (32 halaman), kepustakaan (2 halaman) dan biodata penulis (1 halaman). Bab-bab bagi novel ini dibuat berdasarkan nama watak yang susunannya berselang seli yang jumlahnya tidak sama banyak; Bab Abdul Hafiiz 10, Bab Salinah 9, Bab Dato Mansor 1, bab Datin Mahani 1. Sebagai permulaannya ialah Bab "On your mark! Get set! Ada 1 bab dan 1 bab juga untuk Bab "go!" sebagai bab penutup novel $S$ ini. Jadi keseluruhannya ada 23 bab yang terdapat dalam novel ini. Novel $S$ ini bersaiz $14 \times 21.5 \mathrm{~cm}$ dengan kulit berwarna kekuningan hasil reka bentuk Pengiran Timbang Pengiran Haji Tuah yang berbentuk pelan kampung Saba dibuat secara abstrak dengan menyatakan kedudukan kampung-kampung; Saba Ujung, Saba Tengah, Saba Laut, Saba Darat dan Lurung Sikuna (nama-nama tempat itu dieja secara terbalik). Inilah ciri-ciri khas novel $S$ dari segi fizikalnya.

Seperti keadaan alam dan unsur alam yang lain, teks ini mengandungi kepelbagaian, keseimbangan dan keharmonian atau kesatuan dari segi bentuknya yang merupakan nilai keindahan bagi karya sastera seperti penyataan (Braginsky 1979, p. 6) dan terjemahannya (Lutfi Abas, 1995, p. 51):

Maka kita melihat yang indah (menurut Melayu) adalah sebagai sesuatu yang luar biasa yang kepelbagaian atau keragaman pernyataannya diatur atau diharmonikan dengan baik

\section{Kepelbagaian}

Dalam novel $S$ ini agak banyak unsur kepelbagaiannya, antaranya termasuklah kepelbagaian sudut pandangan, tajuk dan jumlah muka surat setiap bab, bahasa, watak, ejaan, dan genre. Novel ini memaparkan banyak sudut pandangan orang pertama melalui watak Abul Hafiiz, Saliah, Dato Mansor 
dan Datin Maimunah di samping Daniel (dalam catatannya yang dibaca oleh Abdul Hafiiz). Kesemuanya bukan watak utama dalam novel ini yang bererti novel $S$ ini tidak ada watak utama. Kepelbagaian lain novel $S$ ialah pada babbabnya yang ditandakan dengan nama watak seperti yang disebut di atas di samping watak dalam bab pendahuluan yang bertajuk "on your mark! Get set" dan bab terakhir atau penutupnya "Go!". Bab-bab lain menggunakan nama watak sementara dua bab (awal dan akhir) menggunakan bahasa Inggeris dan bukan watak. Selain itu, panjang setiap bab juga tidak sama. Ada bab yang sepanjang satu muka surat, iaitu bab pembukaan dan penutup dan yang terpanjang ialah tiga puluh enam, bab yang bertajuk Abdul Hafiiz pada halaman 132 hingga 195.

Novel $S$ ini ialah cerita berbingkai, iaitu hasil catatan watak Daniel. Kepelbagaian tajuk babak bagi catatan yang dibuat oleh watak Daniel dalam novel $S$, berbeza dengan yang dibuat oleh JaBit Abdul Aziz(pengarang) dalam novel $S$. Dalam catatan yang dibuat oleh watak Daniel, tajuknya bermula dengan "On your mark!": Dunia ini Memang Celaka? (p. 21) dan bab yang terakhir "On your mark!" itu: Penarik Beca (p. 195). Catatan watak Daniel itu tidak semua dapat dibaca. Mulai daripada catatan bertajuk "On your mark!": Sprinkler System sehingga yang terakhir itu (13 semuanya) hanya tajuknya disenaraikan dalam novel ini, dengan kata lain, tidak ada paparan cerita pada tajuk-tajuk itu. Jumlah tajuk yang demikian pada catatan watak Daniel ialah 47 semuanya termasuk yang perlu dibaca oleh Abdul Hafiiz itu. Tajuk catatan watak Daniel itu dipelbagaikan juga, termasuk bab atau tajuk yang konsisten “on your mark!”: Bukan Salahku yang sebanyak 10 semuanya dan tajuk yang menggunakan nama ahli keluarga watak Daniel. Jadi bilangan tajuk catatan watak Daniel lebih banyak daripada bab novel JaBit. Cerita berbingkai dalam novel ini ialah salah satu daripada kepelbagaian naratif dalam novel $S$.

Watak dalam novel ini pelbagai latar belakang dan juga status sosial; ada yang bekerja sebagai nelayan, penambang, pengusaha, penagih dadah, pengedar dadah, wartawan jujur dan peguam. Di samping itu, kepelbagaian juga terdapat pada pemilihan watak dan nama watak. Ada watak rekaan dan ada juga watak orang yang benar-benar wujud. Hal ini pernah dilakukan oleh Mussidi dan juga Rahim A.B.. Watak itu juga dipelbagaikan lagi dengan bangsa, sikap dan sifat serta agama. Watak rekaan itu terdiri daripada orang Melayu, Orang Inggeris, orang Finland, dan Orang Jerman. Sementara nama watak yang benar-benar wujud ialah Haji Jabit, iaitu pengarang novel ini sendiri. Sesuai dengan kepelbagaian bangsa dalam watak, penggunaan 
bahasa dalam novel ini dapat dikesan kepelbagaiannya, iaitu bahasa Melayu Brunei, bahasa Melayu standard, bahasa Iban (p.138) dan bahasa Inggeris (terdapat di mana-mana antaranya halaman 109 dan halaman 199 -201).

Seterusnya novel S ini mempelbagaikan bentuk ejaan seperti ejaan "gustan 360" (terbalik), ejaan tidak lengkap seperti "Saliah sempat dic..." (p.143) , “... Tali aku tahu memang mengambil d....” (p. 150), dan yang lain-lainnya terdapat pada halaman 151, dan 152. Ejaan dalam novel ini terdapat dalam saiz fon, bentuk fon \& tanda baca yang berbagai-bagai pada tajuk bab dan juga teksnya. Kepelbagaian novel $S$ yang lain ialah pada genre yang terdapat di dalamnya. Novel $S$ ini memasukkan cerpen (pe.ta. karya Haji JaBit) (pp. 61 - 72), dairi atau catatan (pp. 138 - 195), naratif, fakta (tentang tempat dan syarat-syarat menjadikan sesuatu tempat itu sebagai warisan dunia yang disalin daripada internet. Fakta ini terdapat pada halaman 35 hingga 60, kertas kerja Simposium Antarabangsa Kampung Air (SAKA) pada halaman 183 hingga 192, petikan buku Pentadbiran Awam Brunei Darussalam di Period Naungan dan Pemerintahan Sendiri: Satu Kajian tulisan Haji Duraman Tuah (p. 181) dan terjemahan al-Quran (p. 198).

\section{Keseimbangan}

Dalam kepelbagaiannya itu terdapat keseimbangannya. Kepelbagaian yang dinyatakan di atas bukan dalam bentuk yang rencam. Seperti alam yang sebenar yang terdapat kepelbagaian namun wujud dalam keadaan yang seimbang. Sebagai contoh dalam hutan terdapat pelbagai hidupan di dalamnya. Kewujudannya itu sentiasa dalam keadaan yang seimbang. Umpamanya di tempat yang ada berbukit-bukau pasti ada alur atau sungai di situ. Kalau tidak pun pasti adanya jurang yang merupakan bahagian yang paling rendah. Demikian juga dengan hidupan di dalamnya, ada yang sesuai dalam air, ada juga yang sesuai di darat. Demikian juga dengan novel $S$ ini. Antara keseimbangan itu ialah susunan babnya yang mengandungi pengenalan dan penutup. Begitu juga dengan jumlah bab; bab Abdul Hafiiz (10 bab) hampir seimbang dengan bab Saliaha (9 bab). Dua bab yang lain menggunakan nama watak Dato Mansor dan isterinya Datin Mahani. Penggunaan kedua-dua watak tersebut juga seimbang dengan masingmasing hanya ada satu bab sahaja. Keseimbangan yang lain juga terdapat pada jumlah muka surat bab pembukaan dan penutup yang benar-benar seimbang kerana mengandungi satu halaman.

Keseimbangan itu berlaku juga pada naratif novel $S$; di samping cerita fiksyen terdapat juga fakta di dalamnya, iaitu mengenai tapak warisan dunia 
lengkap dengan nama tempat yang wujud di dunia serta peraturan untuk menjadikan sesuatu tempat itu sebagai tapak warisan dunia. Jadi dalam novel ini pembaca tidak hanya mendapat cerita tetapi juga disogok dengan ilmu pasti (fakta) di dalamnya. Jika sekiranya, ilmu tersebut ditulis dan diterbitkan dalam buku khusus membicarakan mengenainya, tidak ramai pembaca yang akan membaca. Namun begitu, apabila perkara itu diselitkan dalam fiksyen, secara tidak langsung, pembaca akan membaca perkara itu. Dengan cara ini akan memperkaya pengetahuan mereka. Pengetahuan itu terdapat dalam keadaan yang seimbang; pengetahuan tentang cerita dan juga fakta yang ada.

\section{Keharmonian}

Keharmonian dalam karya sastera wujud apabila ada kesesuaian, keserasian dan kemesraan antara unsur-unsur di dalamnya. Dalam novel $S$ keharmonian dapat dikesan sekurang-kurangnya dari dua segi. Pertama, pada dua cerita yang digabungkan dalam naratif novel ini, iaitu cerita yang berlaku pada watak Abdul Hafiiz (cerita utama) dan cerita daripada catatan watak Daniel. Kedua-dua cerita tersebut terdapat kesesuaiannya dan dapat disatukan untuk menjadi sebuah teks yang lengkap. Demikian juga dengan catatan ilmiah mengenai warisan dunia yang dikutip atau dipetik daripada sumber internet oleh Abdul Hafiiz, memperkukuh makna naratif novel ini.

Unsur keharmonian kedua ialah susunan bab yang menggunakan namanama watak dalam novel. Walaupun ceritanya mengenai watak berdasarkan tajuk, perjalanan plot cerita dalam naratif secara keseluruhannya tidak terganggu kerana setiap satunya merupakan cerita yang berada dalam satu landasan perkembangan plot yang satu. Penceritaannya berlaku dengan harmoni sehingga ke titik puncak yang akhirnya mencapai sasarannya, iaitu pemikiran atau tema yang hendak disampaikan oleh pengarangnya. Hal ini membuktikan bahawa novel ini sebagai objek alam, dan terdapat keharmonian di dalamnya.

\section{Karya Sastera sebagai Subjek Alam}

Karya sastera yang dianggap sebagai subjek alam itu ialah naratifnya. Kewujudannya melibatkan proses pembentukan sebagai hasil ciptaan pengarang. Berdasarkan teori ini, naratif dan cerita dalam karya sastera itu disamakan dengan mimpi (sebahagian daripada unsur alam) (Hashim, 2002 dan Chong, 2014 dan 2016). Sebagai mimpi karya sastera merupakan unsur 
metafizik yang misteri sifatnya. Kemisterian itu terdapat pada makna cerita serta pada kewujudan cerita itu sendiri. Misteri dari segi makna disebabkan terdapat dua lapis makna di dalamnya, yang tersurat dan tersirat. Sementara misteri dari segi kewujudannya apabila ceritanya terdapat peristiwa yang pernah berlaku, sedang berlaku, belum berlaku tetapi berkemungkinan boleh berlaku. Juga cerita yang tidak masuk akal diukur daripada ukuran realiti pragmatik berdasarkan pengalaman dan pengetahuan sosiobudaya Melayu-Islam.

Novel $S$ memaparkan cerita yang bermula dengan Daniel mendapat kemalangan kerana dilanggar oleh Abdul Hafiiz bin Dato Mansor. Kejadian itu berlaku kerana Abdul Hafiiz sedang dalam keadaan fikiran yang kurang tenang. Sementara itu, Daniel pula secara tergesa-gesa menyeberang jalan kerana melarikan diri daripada Saman dan kawan-kawannya yang ingin mencederakannya. Akibat perlanggaran itu, Daniel pengsan dan kakinya patah. Melihat keadaan yang mencemaskan itu dia dihantar oleh Abul Hafiiz ke rumah sakit. Sebelum pengsan, Daniel sempat memberikan beg sandangnya kepada Abdul Hafiiz. Saman dan kawan-kawannya mahu melakukan perkara itu kepada Daniel kerana mereka menuduhnya melaporkan kegiatan mereka menghisap dan mengedar dadah di kampung itu. Selain itu, Saman juga berdendam kerana adik Daniel tidak melayan cintanya. Saman hanya berjaya membakar rumah Daniel khususnya Balai Halimah. Ketika itu, Daniel lari meninggalkan rumah sambil membawa beg sandangnya. Dalam kebakaran itu Hajah Ranik binti Tengah dan Putih binti Hitam, ahli keluarga Daniel, telah cedera parah dan dibawa ke rumah sakit.

Ketika dia di rumah sakit, ramai orang melawat Daniel termasuk pelancong dari luar negara. Di situ telah berlaku satu peristiwa atau kejadian, iaitu orang-orang Saman telah menyimbah Daniel dengan air tahi. Orang tersebut tidak berjaya ditangkap. Pada akhir cerita, Daniel balik ke Balai Halimah di kampung air setelah dibenarkan keluar oleh pihak rumah sakit. Di rumahnya, pada malam itu juga, keluarganya mengadakan majlis kesyukuran kerana dia selamat daripada kemalangan yang menimpanya. Di samping ahli keluarga, ada pelancong dari Finland, serta Mark Schmidt (peguam) dan rakan-rakannya yang turut menyambut kepulangan Daniel selain Abdul Hafiiz dan keluarganya. Abdul Hafiiz dan keluarga serta orang-orang asing yang datang ke rumah Daniel itu dibawa ke Balai Halimah (Ba.Hal) yang ada kutubkhanah, bilik mesyuarat dan gym dalam air (p. 137). Selepas sembahyang isyak, Dato Mansor dan keluarga beredar ke bilik mesyuarat. Di situ, empat orang Inggeris yang diketuai oleh Mark Schmidt sedang 
menunggu keluarga Dato Mansor, bapa Abdul Hafiiz. Setelah Dato Mansor tiba, ada perbincangan dia dengan rombongan yang diketuai oleh Mark Schmidt di situ dan di hujung majlis ada penyampaian wasiat bapa Daniel, Christopher Daniel, kepada Daniel dan adik-adiknya. Ketika perbincangan itu diadakan Daniel tidak muncul di bilik mesyuarat kerana dia bersendirian berada di atas balai sedang membaca ayat-ayat suci sehingga beberapa orang lelaki buntak perut buncit (Saman) datang memukul, menyimbahnya dengan asid dan menembaknya. Dengan kematiannya itu, Saman dan orang-orangnya gembira lalu melarikan diri dari Kampung Saba, khususnya Ba.Hal. Abdul Hafiiz dan Haji JaBit cuba mengejar mereka dengan perahu. Namun begitu, tidak jadi kerana dari jauh mereka terdengar bunyi letupan pada perahu yang dinaiki oleh Saman dan kawan-kawannya. Pada malam itu, nenek Daniel Hajah Ranik binti Tengah dan Putih binti Hitam (mangsa kebakaran rumah Daniel) juga meninggal dunia.

Naratif dan cerita dalam novel ini bukan disusun dalam bentuk binaan plot secara linear tetapi agak kompleks sehingga novel ini tidak mengetengahkan hero dari segi wataknya. Keadaan seperti ini sama seperti yang berlaku dalam mimpi. Oleh sebab itu, naratif dan cerita dalam sesebuah karya sastera itu akan menjadi mimpi pembaca dan juga masyarakatnya. Sesuatu mimpi itu berlaku dengan adanya matlamat yang dirancang oleh penciptanya. Untuk mendapatkan maknanya maka maksud perlu ditakwilkan berdasarkan budaya dan ruang lingkup politik masyarakat dan negara tersebut. (Perkara ini tidak akan disentuh di sini dengan lebih mendalam kerana ia menyentuh unsur dalaman teori moral alamiah).

Novel $S$ ini sesuai dengan prinsip dan konsep teori moral alamiah kerana naratifnya mengandungi peristiwa yang beberapa cirinya sama dengan mimpi (objek alam) seperti yang dihuraikan di bawah ini.

\section{Peristiwa yang Pernah Berlaku}

Dalam cerita novel $S$ ini peristiwa yang berlaku dalam dunia nyata adalah seperti kemalangan kereta disebabkan kecuaian pemandu dan pejalan kaki. Kejadian ini berlaku kepada Abdul Hafiiz dan Daniel. Kemalangan ini berlaku di Jalan Subuk. Nama tempat itu memang wujud dan jalannya sentiasa sibuk, dan kemungkinan berlaku kemalangan adalah tinggi jika tidak berhati-hati. Begitu juga hubungan renggang antara anak dan ayah seperti yang berlaku kepada Dato Mansor dengan Abdul Hafiiz. Walaupun mungkin sebabnya berbeza-beza, namun peristiwa seperti ini agak lumrah di mana-mana sahaja di dunia ini. Peristiwa yang lain ialah pergaduhan antara 
pengedar atau penagih dadah dengan orang kampung yang mengambil peduli hal tersebut. Kejadian ini berlaku antara Saman dengan Daniel sehingga menyebabkan kematian kedua-duanya. Peristiwa yang tersebut di atas antara peristiwa yang umumnya boleh berlaku kepada sesiapa sahaja terutamanya di negara Brunei Darussalam seperti yang ada dalam novel $S$.

\section{Peristiwa yang sedang Berlaku}

Peristiwa yang dimaksudkan dengan "sedang berlaku" ialah perbuatan yang dilakukan oleh watak dalam naratif dan cerita novel $S$ sama seperti yang berlaku dalam dunia realiti ketika ini. Perbezaan antara kedua-duanya hanyalah dari segi konteks waktu dan latar. Dalam novel ini tidak banyak peristiwa seperti ini yang dipaparkan. Yang termasuk dalam kategori ini ialah penduduk kampung yang tinggal di kampung air yang diwakili oleh keluarga Daniel. Penduduk di situ berhubung melalui sungai. Oleh itu, perahu tambang merupakan satu-satunya kenderaan penghubung yang utama. Hal ini berlaku di kampung air sehingga pada hari ini.

\section{Peristiwa yang Belum Berlaku tetapi Berkemungkinan Boleh Berlaku.}

Seperti yang dibayangkan oleh makna kata kerjanya, "belum" bererti peristiwa dalam ketegori ini tidak pernah lagi berlaku di negara ini. Pengalaman di negara lain tidak dipertimbangkan di sini kerana pemerhatian ini berdasarkan budaya lokal. Antara peristiwa yang demikian, yang terdapat dalam cerita novel $S$ ialah orang yang dilanggar bersikap baik kepada yang melanggarnya. Peristiwa ini berlaku kepada Abdul Hafiiz apabila Daniel yang dilanggarnya tidak menunjukkan kemarahannya. Malah dia sendiri mengaku salah kerana kelalaiannya. Bukan itu sahaja, dia telah memberikan beg sandang kepada Abdul Hafiiz. Demikian juga dengan sikap orang asing terhadap Daniel. Dalam konteks cerita dalam novel ini, Daniel hanyalah seorang penambang (mengambil upah daripada penumpang yang memerlukan perkhidmatannya menghantar mereka dari satu destinasi ke satu destinasi yang lain). Namun begitu, dia mendapat kepercayaan orang Finland dan aktivis sejarah untuk berjuang mewartakan kampung air sebagai salah satu warisan dunia. Kemungkinan perkara ini berlaku memang ada, namun belum pernah hal ini berlaku di negara ini dalam urusan sedemikian. Biasanya, perkara seperti ini menjadi urusan jabatan atau kementerian tertentu yang ada kaitan dengan sejarah. 
Seterusnya, peristiwa "anak ampang" (anak luar nikah) dalam novel ini yang diangkat menjadi penting. Sejauh ini, berdasarkan pengalaman dan pengetahuan, tidak pernah berlaku dalam konteks negara Brunei Darussalam, ada orang yang mengalami tiga kali peristiwa seperti itu. Dalam novel ini berlaku kepada keluarga Daniel yang mempunyai adik-beradik daripada ayah berbangsa Inggeris, Cina dan India. Selain itu, peristiwa pelawat yang pergi melawat Daniel di rumah sakit juga sesuatu yang belum pernah berlaku. Dalam novel $S$ ini dikatakan terlalu ramai orang yang datang melawatnya sama ada yang datang dari kampung air mahupun orang asing. Mereka terpaksa berbaris panjang untuk menunggu giliran melawat Daniel. Sedangkan Daniel hanyalah seorang penambang atau buruh kasar. Dalam cerita novel ini tidak jelas jasanya kepada masyarakat sehingga dia diambil peduli oleh ramai orang, termasuk orang luar.

Demikian juga halnya yang berlaku kepada Abdul Hafiiz, iaitu seorang peguam yang meninggalkan pekerjaannya dan menceburi kerjaya sebagai wartawan. Peristiwa ini mungkin pernah berlaku tetapi yang mungkin tidak pernah berlaku ialah setelah mendapat syarikat akhbar sendiri Abdul Hafiiz tidak menerbitkan surat khabar itu setiap hari, tetapi seminggu sekali, dan kadang-kadang tidak diterbitkan. Akhbar itu menerbitkan 100 peratus kisah tulen dan benar serta tidak menerbitkan berita yang sensasi. Kejujuran seperti ini jika berlaku, tentulah masyarakat mendapat maklumat yang benar-benar sahih dan bukannya berita yang tidak berfaedah untuk pembangunan insan. Dalam syarikatnya itu, dia melakukan semua kerja sehingga surat khabarnya itu terbit.

\section{Peristiwa yang Tidak Masuk Akal}

Dalam novel $S$ ini juga ada memaparkan beberapa peristiwa yang tidak masuk akal manusia normal berdasarkan budaya negara berkonsepkan Melayu Islam Beraja. Antara peristiwa tersebut ketika berlakunya kebakaran di Kampung Saba, orang kampung cuba sedaya-upaya membantu memadamkan kebakaran dan menyelamatkan kampung terutamanya Ba.Hal. Namun begitu, pada masa tersebut Saman telah mengambil kesempatan meramas buah dada Saliah, seorang gadis kacukan Cina berkulit putih melepak yang digila-gilakannya (adik Daniel). Perbuatannya itu telah dihukum oleh Saliah dengan kelincahan silatnya sehingga Saman terjatuh ke sungai. Tidak puas dengan itu, Saliah ikut terjun dan mengerjakannya sehingga Saman melarikan diri kerana kesakitan dan malu. 
Peristiwa lain yang tidak masuk akal ialah ketika di rumah sakit Daniel yang berkerusi roda dan asyik melayan tetamunya, dia telah disimbah oleh tiga orang pemuda (yang menyamar sebagai pelawat kepadanya) dengan air tahi. Mereka itu gagal ditahan atau ditangkap oleh pengawal keselamatan di rumah sakit itu. Perbuatan seperti ini dianggap tidak masuk akal dalam kehidupan kita sehari-hari. Peristiwa lain pada bahagian terakhir bab, yang berlaku kepada Daniel. Peristiwa ini bermula apabila Abdul Hafiiz, bapa dan ibunya datang ke Ba.Hal. Mereka telah disambut oleh Daniel dan Haji JaBit atau nama sebenarnya Haji Abdul Aziz. Kebetulan pada masa itu azan maghrib dilaungkan, jadi mereka berjamaah dulu. Ketika itu Daniel tidak ada bersama mereka. Tiba-tiba sahaja dia menghilang dan berpindah ke tempat lain.

"Mana Daniel, Haji?"

"Biasalah, dalam masa ini Daniel berada di Menara Pengamatan, tu di sana."

"Apa dibuatnya?"

"Berzikir dan membaca al-Quran."

Kulangoi dekat menara, memang ada cahaya keluar dari sana."

(Haji Abdul Aziz, p. 198)

Demikian juga halnya episod berikutnya selepas sembahyang Isyak, ketika Abdul Hafiiz, bapanya, Haji JaBit, dan Daniel bersama dengan empat orang "putih" di bilik mesyuarat. Di situ, Mark Schmidt selaku ketua dan wakil pengerusi WHAT dan HaDani Corporation mempersilakan Michele Suarrez memberikan taklimat kepada mereka berkenaan dengan projek yang akan mereka bentangkan kepada pihak berkuasa pada hari berikutnya. Selepas itu dia menerangkan tujuan mereka yang penting, iaitu hendak menyampaikan pesanan pengerusi WHAT, Christoper Daniel yang telah meninggal. Wasiat itu adalah untuk Daniel Sahak (anak luar nikah Christoper Daniel). Pesanan itu disampaikan oleh peguamnya, Abdul Malik Hashimi. Sampul surat itu diserahkan kepada Daniel dan penerangan mengenai isi sampul surat itu diterangkan melalui projektor yang menunjukkan Christoper Daniel bercakap kepada Daniel. Isi video itu ialah kisah lalu ibu Daniel dan dirinya. Yang terpenting, dia telah memberikan wasiat harta peninggalannya yang bernilai jutaan pound kepada Daniel dan adik-adiknya. Namun begitu, ketika pengumuman penting itu dibuat oleh bapanya, Daniel tidak berada di situ. 
"Di atas kedengaran bunyi gaplah. Kedengaran: "Di mana Daniel!?"

Di jawab: "Di bawah".

(Haji Abdul Aziz, p. 201)

Keadaan ini bererti Daniel menghilangkan diri. Mereka mengetahui keberadaannya apabila mendengar keadaan huru hara di atas balai. Keduadua peristiwa itu tidak masuk akal berdasarkan kebiasaan hidup masyarakat kita. Sikap Daniel yang menghilangkan diri daripada tetamunya tanpa memberi tahu mereka itu hanya boleh berlaku dalam mimpi. Kedatangan tetamu biasanya dihormati dan dilayan oleh tuan rumah. Tidak seperti watak Daniel yang digambarkan dalam novel ini.

Dengan penjelasan di atas itu dapat dirumuskan bahawa berdasarkan teori moral alamiah ini, karya sastera itu sebahagian daripada objek alam dalam alam fizikal yang mengandungi ciri-ciri kepelbagaian, keseimbangan dan keharmonian atau kesatuan. Dalam pada itu, karya sastera itu juga sebagai subjek alam (alam metafizik). Kewujudannya melalui proses di tangan pengarang yang direstui oleh Tuhan. Sebagai subjek alam bererti karya sastera itu dijadikan sebagai bahan untuk sesuatu manfaat yang lebih daripada fungsinya sebagai objek. Bagi novel $S$, selaku objek yang berbentuk buku. Novel $S$ sebagai subjek pula ialah naratif dalam teks atau buku itu. Dalam naratif ada mengetengahkan peristiwa sama seperti yang terdapat dalam mimpi. Mimpi sebagai unsur alam metafizik, ada terdapat cerita yang pernah berlaku, sedang berlaku, akan berlaku dan juga yang kurang logik, magis dan abstrak.

\section{BERFAEDAH DAN INDAH}

Setelah teks tercipta dan menjadi objek dalam alam realiti (buku dan seumpamanya), ia tidak bermakna apa-apa. Selepas dicetak, buku akan tinggal diam di tempat buku itu disimpan. Jika disimpan di perpustakaan, buku itu akan kekal di situ dengan nilai mukanya yang ada (harga buku). Jadi, kepada pembacalah teks itu terserlah faedahnya dan kegunaannya melalui pengalaman estetik, dan intelek pembaca. Antara faedahnya termasuklah pembaca dapat mengambil iktibar daripada cerita dalam naratif teks itu, dan juga menghayati keindahannya sama ada untuk diri sendiri, masyarakat dan negara. Berdasarkan pembacaan teori moral alamiah, keadaan demikian juga terdapat dalam novel $S$ ini. Oleh sebab analisis hanya pada unsur permukaannya sahaja, jadi manfaatnya kepada manusia hanya berdasarkan 
unsur luaran novel. Antara kegunaannya yang asas, novel ini telah diajukan untuk dinilai bagi menerima Anugerah Penulis ASEAN (South East Asia Write Award) untuk tahun 2015. Novel ini telah mengangkat negara Brunei sebaris dengan negara Asia Tenggara yang lain kerana layak menerima anugerah yang tertinggi itu. Dengan demikian, sudah tentu novel ini menjadi kebanggaan rakyat dan penduduknya.

Berdasarkan perbincangan di atas, novel ini dapat dimanfaatkan oleh para penulis dan bakal penulis. Novel ini memaparkan teknik penulisan yang indah menurut pertimbangan secara universal, iaitu mempunyai kepelbagaian, keseimbangan dan keharmonian. Dengan demikian, novel ini sangat berguna kepada penulis baharu yang ingin menulis gaya pascamoden. Unsur gaya pascamoden yang lain antaranya novel $S$ tidak menentukan watak utamanya. Setiap watak berjalan seiring dari segi peranan dan juga kemunculan mereka. Dan yang penting juga yang boleh diambil iktibar oleh para penulis ialah gaya naratif yang dipaparkan. Novel $S$ memaparkan naratif yang betul-betul menyamai mimpi. Perkara ini dilakukan oleh pengarangnya bukan tanpa ada tujuan. Selaku mimpi, cerita dalam novel ini perlu ditakwilkan dengan saksama berdasarkan budaya lokal masyarakat negara Brunei Darussalam yang berkonsepkan Melayu Islam Beraja. Perbincangan mengenai novel $S$ sebagai objek dan juga sebagai subjek telah menyerlahkan unsur-unsur keindahannya. Keindahan dari segi bentuk serta pada unsur permukaan novel $S$ seperti yang dijelaskan di atas.

\section{KESIMPULAN}

Novel $S$ menunjukkan keserasiannya dengan teori moral alamiah. Dalam satu teks dapat dilihat ciri-ciri alamiahnya yang boleh dimanfaatkan untuk mendapatkan pengalaman dan pengetahuan. Baik dari segi cirinya sebagai objek mahupun sebagai subjek, novel ini memenuhi prinsip dan konsep teori. Sebagai unsur alam, tentu sekali sebagai alamiahnya, mengandungi manfaat kerana prinsip asalnya ialah setiap apa-apa yang terjadi dan dijadikan di dunia ini ada kegunaannya masing-masing. Walau bagaimanapun, maksud kegunaan itu begitu subjektif bergantung pada konteks atau situasi dan juga faktorfaktor lain. Berkenaan novel $S$, berdasarkan perbincangan dalam tulisan ini, dapat disimpulkan bahawa novel ini berguna untuk melihat teknik penulisan pascamoden yang dipelopori penulis Barat. Selain itu, kewujudannya sudah pasti akan memperkaya tamadun bangsa Brunei, tambahan lagi novel ini telah diangkat menjadi sumber kemenangan pengarangnya yang mendapat anugerah tertinggi. Seperti yang dinyatakan sebelum ini, teori 
ini mengandungi dua sisi analisisnya; lapisan luar dan lapisan dalam. Yang terserlah di sini adalah dari segi lapisan luarnya (permukaannya)sahaja. Oleh sebab itu, novel S ini perlu dibuat satu kajian lanjut dengan mengaplikasikan teori ini dari segi dalamannya pula. Kajian yang dimaksudkan itu ialah naratif teks novel $S$ dari sisi metafiziknya yang disamakan seperti mimpi yang penuh misteri sifatnya, namun ada pengalaman dan pengetahuan. Jika ini dapat dilakukan hal ini maka penilaian terhadap makna novel S ini dapat dilaksanakan sepenuhnya.

\section{RUJUKAN}

Ainon Mohd., 2011. Panduan menulis novel: Teknik Surah Yusuf. Kuala Lumpur: PTS.

Chong Ah Fok. (2008). Kajian novel-novel terpilih Brunei Darussalam dari perspektif pengkaedahan Melayu. Brunei Darussalam: Dewan Bahasa dan Pustaka.

Chong Ah Fok. (2016). Teori Moral Alamiah: Satu Gagasan. Kertas kerja Persidangan Antarabangsa Pengajian Alam Melayu 2016, anjuran Institut Alam dan Tamadun Melayu (ATMA), UKM dengan kerjasama Department of South East Asia, SOAS University of London dan Dewan Bahasa dan Pustaka (DBP) di Royal Asiatic Society, London pada 19 hingga 20 September 2016.

Hashim Awang. (Disember 1989). Kajian sastera: Suatu pendekatan Melayu. Dewan Sastera 60-63.

Hashim Awang. (2002). Teori Perkaedahan Melayu dan Prinsip Penerapannya.

Kertas Kerja Bengkel Kajian Teori Sastera Melayu anjuran Bahagian Teori dan Kritikan Sastera. Jabatan Sastera Dewan Bahasa dan Pustaka pada 28 - 29 Jun di Riviera Bay Resort, Melaka.

http://www.primbon.com/tafsir_mimpi.htm [2 Mac 2018]

Muhammad Lutfi Ishak. (Ogos 2016). Pengarang muda yanggungjawab dan cabaran zaman. Dewan Sastera 4 - 9.

Seyyed Hossein Nasr. (1993). Seni dan spiritualitas. Bandung: Mizan.

Wellek, Rene and Austin Warren. (1988). Teori kesusasteraan. Diterjemah oleh Wong Seng Tong. Kuala Lumpur: Dewan Bahasa dan Pustaka.

Yusuf al-Qardawi. (2001). Ilham, kasyaf dan mimpi. Terjemahan. Basri Ibrahim. Kuala Lumpur: Darul Nu'man.

Received: 3 April 2018

Accepted: 5 September 2018 